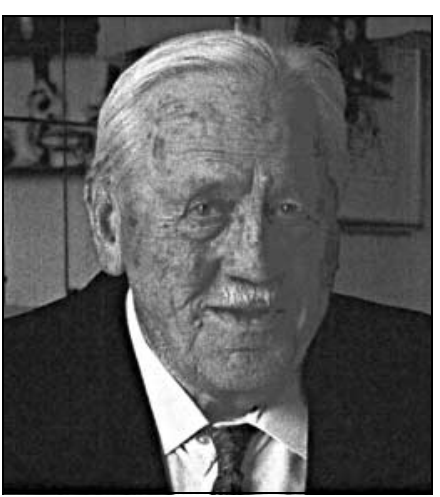

Kenneth Carl Pfeiffer Smith

Formerly Medical Director

Wiltshire Child Guidance Services

Dr Smith (Ken) was a Bristolian from start to finish: he was born in Bristol on 2 March 1910 and died there on 16 October 1999. Educated in the classical tradition in Bristol Grammar School, he studied medicine at Bristol University where he imposed his personality on student life in the 1930s. An outstanding athlete, he played cricket and rugby for the University and might well have gained an England cap, but for the war. His social, artistic and athletic gifts led him to continue student life somewhat longer than he intended. He graduated MRCS, LRCP in 1937, and took a short service commission in the Royal Air Force where he attained the rank of Squadron Leader. He organised and directed his own band and became a nationally known figure in 'Aircraftsman Smith Entertains', a programme popular with the Forces and with civilians. In 1942 he was posted as Medical Liaison Officer to South Africa where his musical and theatrical talents were fully exploited and where, incidentally, he rubbed shoulders with such famous artists as Leslie Howard and Nöel Coward.

On demobilisation in 1946, he specialised in psychiatry. He joined the ex-Service Registrar Training Programme in Bristol Mental Hospital, Fishponds. The return from the Forces of young doctors and nurses hastened the social and clinical revolution in psychiatry and stimulated a heady enthusiasm. This was a time of intellectual ferment, of excitement and of hope. Ken's gaiety and humour greatly enlivened the 'benign uproar' of current debate.

The Fishponds research department, established by Max Reiss, was expanding very rapidly, but the intense initial excitement was unsustainable. Barrow Hospital took over the main acute psychiatric services of Bristol when it was evacuated by the Royal Navy (1947), the National Health Service (1948) was accompanied by great uncertainties, the expectations of the research department faded. Ken passed the Bristol and the Conjoint DPM but his idealism waned, soon afterward and he went into general practice. The waxing discontent and staff exodus which he joined, led to his aphorism: "Bristol has turned out some good psychiatrists". Later he joined Dr Robert Barbour's newly established Child Guidance team and in 1950 was appointed Medical Director of the Wiltshire Child Guidance Service, a position which he occupied until retirement in 1980. He also did consultant work with the Gloucester and the North Somerset Child Guidance Services and with HM Prison Service. In the late 1950s he researched and presented a programme on left-handedness produced by $\mathrm{Dr}$ Jakob Bronowski, one of the first TV programmes to deal seriously from a psychological view point, with a topic of everyday interest.

He was a Foundation Member of the Royal College of Psychiatrists and a frequent attender at South-Western Division meetings, which he often stimulated by thoughtful, provocative contributions to current debate. He never sought office in the College, but he was Chairman of the local branch of the British Medical Association in the 1960s.

In the mid-1970s, he and his son Dr Michael Apter postulated the reversal theory of psychopathology, a general theory of personality, emotion, motivation and stress which has generated research in 30 countries, 10 books and 10 biennial conferences, the next in 2001 in Hobart, Tasmania.

His obituary notice in his hometown Evening Post recorded his medical contribution to local life, his fame as a musical entertainer and his cricketing and rugby achievements. But his interests were wider still. He had a vast knowledge of ceramics, glass, paintings, books and furniture. Wit, music and poetry ran through his life. His ditties lit up the hospital in the late 1940s.

"Are you weary, are you languid, are you sore depressed. Get the box and set the clocks and Klein will do the rest".

And there were many more.

He would have been 90 next March. He was clear as a bell to the end. $\mathrm{He}$ is survived by his wife Vera, herself an artist and potter of more than local reputation, his sons Michael and Paul and five grandchildren.

\section{F. Early}

\section{William Edward Wilfred Bridger}

Formerly Physician Superintendent, Mendip Hospital, Wells, Somerset

Dr Bridger was born in September 1914. He studied medicine at Guy's and qualified MRCS Eng.LRCP London in 1938, and graduated MB.BS London in 1939.

Drawn to psychiatry, he obtained the DPM Eng. in 1940, but his career was interrupted by the Second World War. He served in the Royal Army Medical Corps reaching the rank of Major, with the responsibility of Adviser in Psychiatry to the South-East Asia command.

In 1944 Bridger was awarded the MD and in 1971 was elected to the Foundation Fellowship of the Royal College of Psychiatrists. Inter alia, he served as Deputy Superintendent at Fair Mile Hospital, Wallingford, Oxfordshire, and then as Physician Superintendent at Mendip Hospital, Wells, Somerset. His interest in forensic psychiatry led to his appointment as Visiting Psychiatrist to HM Prison Shepton Mallett.

He died aged 84, in June 1999.

Henry Rollin

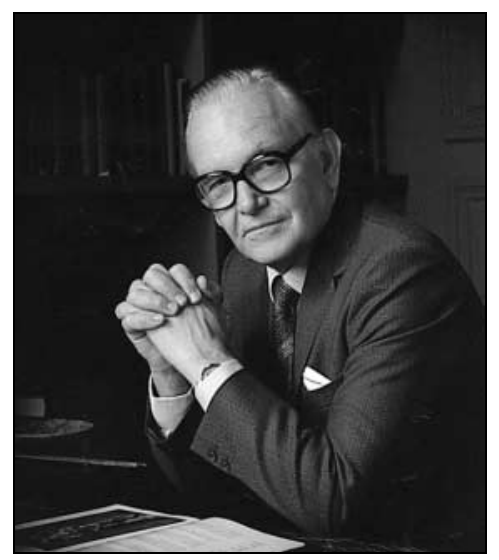

\section{John Anthony Harrington}

Formerly Consultant Psychiatrist and Medical Director, Uffculme Clinic, Birmingham

Dr Harrington made an enormous contribution to psychiatric training and research and to clinical practice in psychotherapy in Birmingham and the West Midlands, and he was the first Director of Postgraduate Psychiatric Education in the West Midlands Region. Generations of trainees are grateful to him, both for the unique and innovative scheme that he developed in 